\title{
Agronomic, morphogenic and structural characteristics of tropical forage grasses in northeast Brazil
}

\author{
ROSANE C. RODRIGUES ${ }^{1}$, THIAGO V.R. SOUSA ${ }^{1}$, MARIA A.A. MELO ${ }^{1}$, JOCÉLIO S. ARAÚJO ${ }^{1}$, \\ ROGÉRIO P. LANA ${ }^{2}$, CLÉSIO S. COSTA ${ }^{1}$, MARIA ELIZABETE OLIVEIRA ${ }^{3}$, MICHELLE O.M. PARENTE ${ }^{1}$ \\ AND IVAN B.M. SAMPAIO ${ }^{4}$ \\ ${ }^{1}$ Universidade Federal do Maranhão, Centro de Ciências Agrárias e Ambientais, Chapadinha, MA, Brazil. \\ www.ccaa.ufma.br \\ ${ }^{2}$ Universidade Federal de Viçosa, Viçosa, MG, Brazil. www.ufv.br \\ ${ }^{3}$ Universidade Federal do Piauí, Teresina, Piauí, Brazil. www.ufpi.br \\ ${ }^{4}$ Universidade Federal de Minas Gerais, Belo Horizonte, MG, Brazil. www.ufmg.br
}

Keywords: Andropogon gayanus, Brachiaria spp., Panicum maximum, forage production, leaf elongation rate.

\begin{abstract}
The objective of this study was to assess the agronomic, morphogenic and structural characteristics of tropical forage grasses during the establishment phase and throughout the second year in northeast Brazil. The treatments included 9 grasses: Brachiaria humidicola (koronivia grass), Brachiaria hybrid cv. Mulato, Brachiaria brizantha cvv. Piatã, Xaraés and Marandu, Brachiaria ruziziensis (ruzi grass), Brachiaria decumbens (signal grass), Panicum hybrid cv. Massai and Andropogon gayanus (gamba grass). The grasses were planted in a randomized complete block design with 4 replications. The following parameters were measured: total forage production, leaf:stem ratio, tiller population density, number of dead tillers, leaf emergence rate, phyllochron, leaf elongation rate, stem elongation rate, rate of leaf senescence, final length of leaf blade and life-span of leaves. In the establishment year, cv. Mulato produced the highest forage yields, followed by cvv. Xaraés and Massai, with gamba grass and koronivia grass worst. In the second year, cvv. Mulato, Xaraés and Marandu, and gamba grass showed highest forage production, while cvv. Massai and Piatã produced the least. All grasses showed a marked drop in production during the dry season. Cultivar Massai consistently had the highest leaf:stem ratio. The morphogenic and structural characteristics differed according to cultivar and season of the year. In general, leaf emergence rate, leaf elongation rate, stem elongation rate, rate of leaf senescence, final length of the leaf blade, number of live leaves per tiller and density of living tillers were higher in the rainy season, while the phyllochron and life-span of leaves were higher in the dry season. The results of this research highlight the potential of the Brachiaria cultivars Mulato and Xaraés, gamba grass and Panicum cv. Massai in subhumid Maranhão, northeast Brazil.
\end{abstract}

\section{Resumen}

El estudio se realizó en el nordeste de Brasil con el objetivo de evaluar las características agronómicas, morfogénicas y estructurales de 9 gramíneas forrajeras tropicales durante la fase de establecimiento y el primer año de producción. Los tratamientos incluyeron: Brachiaria humidicola, Brachiaria híbrido cv. Mulato, Brachiaria brizantha cvs. Piatã, Xaraés y Marandu, Brachiaria ruziziensis, Brachiaria decumbens, Panicum híbrido cv. Massai y Andropogon gayanus. Las gramíneas fueron sembradas en un diseño de bloques completos al azar con 4 repeticiones. Se midieron los parámetros siguientes: producción total de forraje; relación hoja:tallo; densidad populacional de rebrotes; número de rebrotes muertos; tasa de aparición foliar; filocrono; tasas de elongación de hojas y tallos; tasa de senescencia foliar; longitud final de la lámina foliar; y duración de la vida útil de las hojas. En el año de establecimiento, Brachiaria híbrido cv. Mulato produjo los mayores rendimientos de forraje, seguido por B. brizantha cv. Xaraés y Panicum híbrido cv. Massai, siendo A. gayanus y B. humidicola los de peor desempeño. En el segundo año, los cvs. Mulato, Xaraés,

Correspondence: R.C. Rodrigues, Universidade Federal do Maranhão, Centro de Ciências Agrárias e Ambientais, BR 222, km 04, Boa Vista, Chapadinha CEP 65500-000, MA, Brazil.

E-mail:rosanerodrig@gmail.com 
Marandu y A. gayanus presentaron las mayores producciones de forraje, mientras que los cvs. Massai y Piatã fueron los menos productivos. Todas las gramíneas evaluadas presentaron una marcada reducción de la producción durante la estación seca. Panicum híbrido cv. Massai presentó consistentemente la mayor relación hoja:tallo. Las características morfogénicas y estructurales difirieron según la variedad y la época del año. En general, la tasa de aparición foliar, las tasas de elongación de hojas y tallos, la tasa de senescencia foliar, la longitud final de la lámina foliar, el número de hojas vivas por rebrote y la densidad de rebrotes vivos fueron mayores en la época de lluvias, mientras que el filocrono y la vida útil de las hojas fueron mayores en la época seca. Los resultados de esta investigación muestran el potencial de Brachiaria híbrido cv. Mulato, B. brizantha cv. Xaraés, Panicum cv. Massai y A. gayanus en la parte subhúmeda del estado Maranhão en el nordeste de Brasil.

\section{Introduction}

Brazil has an area of more than 220 Mha of pastures, and at least 100 Mha of these are sown pastures (IBGE 2004). Thus, tropical grasslands represent an important resource for the Brazilian cattle industry, which is heavily dependent on grazed pastures (Faria et al. 2013).

Sown pasture grasses in Brazil differ in growth rate, nutrient requirements and sensitivity to water stress. Grasses in the genus Brachiaria have advantages over those in other genera, including good adaptation to acidic soils, tolerance of infertile soils and high dry matter yield. As a result, Brachiaria spp. are the most commonly used grasses in Brazilian pastures (Macedo 2005), and it is estimated that in the mid-western region of Brazil, $50 \%$ of sown pastures are B. brizantha cv. Marandu. Recently, 2 new cultivars of $B$. brizantha (cvv. Xaraés and Piatã) were introduced. Cultivar Piatã has the advantage of promoting slightly higher animal performance in the dry season. These cultivars, released by EMBRAPA (Brazilian Agricultural Research Corporation), flower at different seasons of the year (cv. Piatã in early summer, cv. Marandu in late summer and cv. Xaraés in autumn). This difference favors the strategic use of these grasses, taking advantage of the higher nutritional value and productivity of each cultivar in different periods.

Andropogon gayanus (gamba grass) is used widely in Brazil. It is tolerant of pests, and has high adaptation to arid conditions, high palatability and great potential for producing dry matter in sandy, acidic and infertile soils (Nascimento and Renvoize 2001).

Cultivar Massai, a natural hybrid of Panicum maximum and Panicum infestum, originates from Tanzania, Africa, and was released by CNPGC/EMBRAPA (Vilela 2012). This grass exhibits rapid establishment and regrowth and excellent forage production. Massai is better adapted to infertile soils than other cultivars of $P$. maximum, and has good resistance to leafhopper infestations. Brâncio et al. (2003) showed that Massai was as productive under rotational grazing as cvv. Mombaça and Tanzânia.
Owing to the range of species and environments, knowledge of the morphophysiological characteristics of these grasses is urgently needed to assist in the formulation of management practices. In tropical forage grasses, the morphogenic and structural characteristics can be expressed by leaf emergence rate, leaf elongation rate, stem elongation rate, life-span of leaves, leaf:stem ratio, final length of the leaf blade, number of live leaves per tiller and density of living tillers.

As these grasses were introduced relatively recently and the majority of research has been done in regions that differ significantly from the northeast region, this work aimed to compare the agronomic, morphogenic and structural characteristics of 9 tropical forage grasses during the establishment phase over 2 years in northeast Brazil.

\section{Materials and Methods}

The study site

The experiment was conducted in an area of the Forage Production Sector belonging to the Center for Agronomical and Environmental Sciences of the Federal University of Maranhão, in the lower Parnaíba river region,

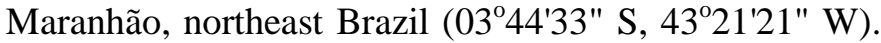
The climate in the studied region has 2 well-defined seasons: a dry season (July-December) and a rainy season (January-June). The soil was a Yellow Latosol, with chemical properties of: $\mathrm{pH}\left(\mathrm{CaCl}_{2}\right)=4.2$; organic matter $=19 \mathrm{~g} / \mathrm{dm}^{3} ; \mathrm{P}, \mathrm{S}, \mathrm{B}, \mathrm{Cu}, \mathrm{Fe}, \mathrm{Mn}$ and $\mathrm{Zn}=5,9,1.43,0.2$, 55, 0.4 and $0.3 \mathrm{mg} / \mathrm{dm}^{3}$, respectively; K, Ca, H+L (potential acidity), aluminum, CEC (cation exchange capacity) and SB (sum of bases) $=0.4,5,2,29,8,36$ and $7 \mathrm{mmolc} / \mathrm{dm}^{3}$, respectively; $\mathrm{V}$ (base saturation) $=20 \%$; and $\mathrm{m}$ (aluminum saturation) $=52 \%$.

\section{Experimental setup}

The area where the experiment was carried out was covered by Cerrado, the typical native vegetation. In February-March of 2010, the area was cleared and treated 
with limestone with reactive power of $94 \%$ of the total neutralization to give a base saturation of $60 \%$. The experimental area was $430 \mathrm{~m}^{2}$, divided into 36 plots of $3 \mathrm{x}$ $2 \mathrm{~m}$, separated by $1.0 \mathrm{~m}$ buffers.

Treatments included the following 9 tropical forage grasses: Brachiaria humidicola (koronivia grass); Brachiaria hybrid cv. Mulato (Mulato); Andropogon gayanus (gamba grass); Brachiaria brizantha cvv. Piatã (Piatã), Xaraés (Xaraés) and Marandu (Marandu); Panicum hybrid cv. Massai (Massai); Brachiaria ruziziensis (ruzi grass); and Brachiaria decumbens (signal grass). The treatments were allotted to a randomized complete block design with split plot, grasses in plots and season of year (dry and rainy) in subplots, with 4 replications.

Seed of the grasses was broadcast at $2 \mathrm{~kg}$ pure viable seed/ha on to the appropriate plots, except for $B$. humidicola, which was vegetatively planted in furrows, on 24 April 2010. At sowing, simple superphosphate and potassium chloride were broadcast on to plots at rates of $500 \mathrm{~kg}$ P/ha and $67 \mathrm{~kg} \mathrm{K/ha.}$

\section{Sward management}

In 2010, plots were cut at $20 \mathrm{~cm}$ above ground level on 2 occasions (a standardization cut 105 days after sowing and a second cut to evaluate grass establishment on 28 August 2010). Plots were fertilized with urea at $50 \mathrm{~kg}$ $\mathrm{N} / \mathrm{ha}$ on each occasion.

In 2011, another standardization cut was performed on 4 January, followed by maintenance fertilization with $333 \mathrm{~kg} \mathrm{P} / \mathrm{ha}$ and $67 \mathrm{~kg} \mathrm{~K} / \mathrm{ha}$. $\mathrm{N}$ was applied as urea at $150 \mathrm{~kg} \mathrm{~N} / \mathrm{ha} / \mathrm{yr}$ as equal split dressings after each harvest.

\section{Measurements}

Total forage production was measured by cutting plots at 28-day intervals during the rainy season and 60-day intervals during the dry season. Material from a square quadrat of $0.25 \mathrm{~m}^{2}$ in the center of each plot was cut to $20 \mathrm{~cm}$ for all cultivars except koronivia grass, which was cut to $15 \mathrm{~cm}$, and was sorted into leaf blade, stem + sheath and dead material to determine the percentage of each morphological component and leaf:stem ratio (LSR) after drying in a forced-draught oven. After weighing the harvested forage, samples were taken to determine the dry matter (DM) content for calculation of DM yield.

Tiller population density (TPD) and number of dead tillers (NDT) within the quadrat were recorded immediately before harvesting. Ten vegetative tillers were marked in each quadrat and measured on a weekly basis, and new tillers were marked after each cut. The following variables were calculated: stem elongation rate (SER, the difference between the initial and final stem lengths, divided by the number of days in the evaluation period); number of live leaves per tiller (NFLT, number of live leaves present at the end of each evaluation period divided by the number of living tillers); density of living tillers (DLT, number of living tillers at the end of each evaluation period); final length of the leaf blade (FLLB, length from the apex to the ligule of fully expanded leaves); leaf elongation rate (LElR, the difference between the initial and final lengths of the leaf blades, divided by the number of days in the trial period); life span of leaves (LSL, the time during which the leaf remained alive after complete exposure of the ligule); leaf emergence rate (LEmR, number of leaves on the tillers marked in each parcel, divided by the number of days in the trial period); rate of leaf senescence (RLS, the area of senescent leaf blades on the marked tillers); and phyllochron (FYLL, the time between the appearance of successive leaves on a tiller).

\section{Data analysis}

The data were grouped based on whether they were from the rainy (January-June) or dry (July-December) season and were submitted to an analysis of variance F-test; in the case of a significant difference, a comparison of averages with Student's t-test at 5\% probability was performed.

In the case of variables with a coefficient of variation (CV) of more than 50\%, such as DLT, NDT, RLS, LSL, FYLL and LEmR, a Kruskal Wallis non-parametric analysis was performed and data are represented by medians. In the case of a difference, Student's t-test at 5\% probability was performed. InfoStat ${ }^{\circledR}$ (InfoStat Statistical Software, Universidad Nacional de Córdoba, Argentina, version 2004) was used for all computations.

\section{Results}

\section{Climatic conditions}

In 2010, when the data were collected during the dry season, average temperature varied from $27.0{ }^{\circ} \mathrm{C}$ (July) to $29.0{ }^{\circ} \mathrm{C}$ (December). In the 2011 rainy season, average temperature ranged from $26.3{ }^{\circ} \mathrm{C}$ (January) to 26.7 ${ }^{\circ} \mathrm{C}$ (June). Rainfall in 2010 was much lower than in 2011 (Figure 1). In the rainy season of the second experimental year, the accumulated rainfall was $1,900 \mathrm{~mm}$ (18.7\% above 10-year mean), with $300 \mathrm{~mm}$ (36.9\% above 10-year mean) in the dry season, and no rainfall during August-September. 


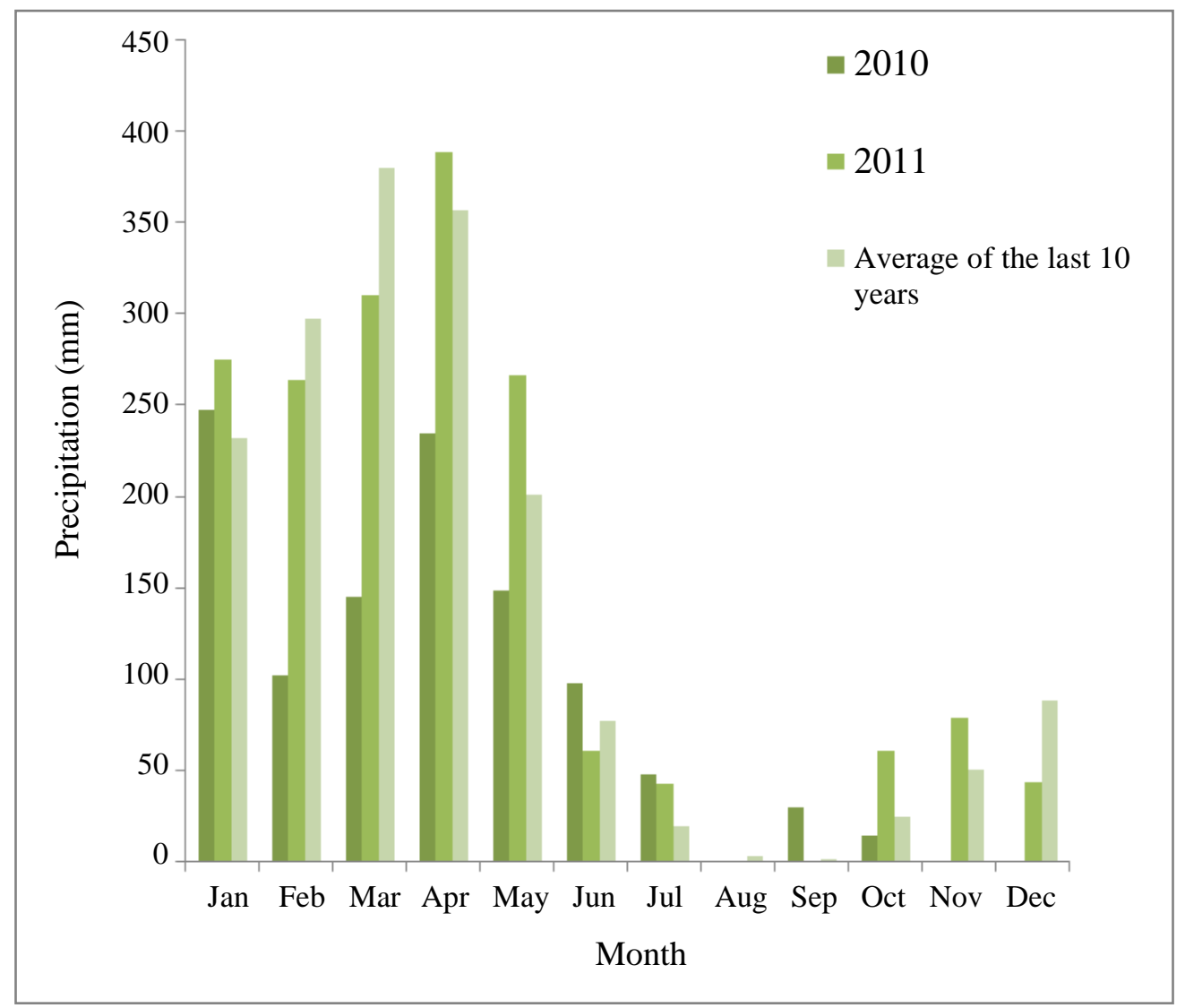

Figure 1. Precipitation during the experimental period and the average of the last 10 years.

\section{Sward variables in the establishment year}

During pasture establishment, forage production, leaf: stem ratio, tiller population density and number of dead tillers differed among the grasses (Table 1). In absolute terms, Mulato produced the most forage and koronivia grass and gamba grass the least, but only some differences between cultivars were significant. Leaf:stem ratio for Massai (13.5) was greater than for all other cultivars (range 1.0-3.7) (Table 1). The same pattern was displayed for tiller population density, with Massai (103) producing more than other cultivars (range 28.6-48.7).

Table 1. Total forage production, leaf:stem ratio, tiller population density and number of dead tillers of 9 tropical forage grasses during the establishment phase.

\begin{tabular}{lcccc}
\hline Cultivar & $\begin{array}{c}\text { Total forage production } \\
(\mathrm{kg} \mathrm{DM} / \mathrm{ha})\end{array}$ & $\begin{array}{c}\text { Leaf:stem ratio } \\
4,745 \mathrm{~d}^{1}\end{array}$ & $\begin{array}{c}\text { Tiller population density } \\
\left(\text { tillers } / \mathrm{m}^{2}\right)\end{array}$ & $\begin{array}{c}\text { Number of dead tillers } \\
\left(\text { No./ } \mathrm{m}^{2}\right)\end{array}$ \\
\hline Koronivia grass & $1.04 \mathrm{~b}$ & $28.63 \mathrm{~b}$ & $0.56 \mathrm{c}$ \\
Marandu & $8,478 \mathrm{bc}$ & $2.75 \mathrm{~b}$ & $36.57 \mathrm{~b}$ & $1.43 \mathrm{bc}$ \\
Xaraés & $11,636 \mathrm{~b}$ & $1.01 \mathrm{~b}$ & $41.54 \mathrm{~b}$ & $2.99 \mathrm{abc}$ \\
Piatã & $6,708 \mathrm{~cd}$ & $2.83 \mathrm{~b}$ & $48.72 \mathrm{~b}$ & $2.46 \mathrm{abc}$ \\
Mulato & $18,620 \mathrm{a}$ & $1.33 \mathrm{~b}$ & $33.84 \mathrm{~b}$ & $0.00 \mathrm{c}$ \\
Signal grass & $8,940 \mathrm{bc}$ & $0.63 \mathrm{~b}$ & $28.78 \mathrm{~b}$ & $4.75 \mathrm{abc}$ \\
Ruzi grass & $6,972 \mathrm{~cd}$ & $3.68 \mathrm{~b}$ & $46.53 \mathrm{~b}$ & $25.88 \mathrm{a}$ \\
Massai & $10,135 \mathrm{bc}$ & $13.51 \mathrm{a}$ & $103.50 \mathrm{a}$ & $8.95 \mathrm{abc}$ \\
Gamba grass & $4,782 \mathrm{~d}$ & $3.26 \mathrm{~b}$ & $31.58 \mathrm{~b}$ & $22.38 \mathrm{abc}$ \\
\hline
\end{tabular}

${ }^{1}$ Means within columns followed by the same letter do not differ by Student's t-test ( $\left.\mathrm{P}>0.05\right)$. 


\section{Sward variables in the second year}

Cultivars Mulato and Xaraés had the highest annual forage production, which did not differ from Marandu, gamba grass and koronivia grass, although yields were 17.3, 17.7 and $23.2 \%$ lower than the average production of the former 2 cultivars, respectively. Signal grass, ruzi grass and Piatã had intermediate performance, while Massai had the worst performance (Table 2).

In the rainy season of 2011, there was a gradation in yield from Mulato $(20,850 \mathrm{~kg} / \mathrm{ha})$ to Massai $(8,939$ $\mathrm{kg} / \mathrm{ha})(\mathrm{P}<0.05)$. In the dry season, yields ranged from $5,180 \mathrm{~kg} / \mathrm{ha}$ (Mulato) to $1,803 \mathrm{~kg} / \mathrm{ha}$ (ruzi grass) ( $\mathrm{P}>0.05)$, with significant $(\mathrm{P}<0.05)$ difference between seasons for all cultivars.

Massai had the highest leaf:stem ratio (LSR) in both wet and dry seasons, but differences between cultivars were rarely significant. Again LSR was higher in all cultivars in the dry season than in the wet season, but differences were generally not significant $(\mathrm{P}>0.05)$.

Koronivia grass and Massai produced more tillers in the rainy season than the other cultivars, but differences were rarely significant. Number of dead tillers was also higher in koronivia grass and Massai in the wet season, but differences were not so marked in the dry season.

In the rainy season, leaf emergence rate (LEmR) did not differ $(\mathrm{P}>0.05)$ among cultivars (Table 3$)$. However, there was variation between periods, with lower values in the dry season $(\mathrm{P}<0.05)$ for most cultivars. Massai presented the smallest LEmR, and koronivia grass the largest.

For all cultivars, phyllochron was greater $(\mathrm{P}<0.05)$ in the dry than in the rainy season (Table 3 ) and there were differences between cultivars during the dry season $(\mathrm{P}<0.05)$. Xaraés and Massai had greater phyllochron and took longer to exhibit 2 consecutive leaves, 48 and 61 days, respectively, than koronivia grass (20.3 days). This may be because the sheath needed to go further between the apical meristem and the end of the pseudostem, as Xaraés presented one of the largest final leaf blade lengths (see Table 4). Koronivia grass required less time for the emergence of 2 consecutive sheaths, possibly due to the smaller size of the leaf blade observed in this species.

Leaf elongation rate (LEIR) during the rainy season varied from $6.02 \mathrm{~cm} /$ tiller/d in gamba grass to 1.27 $\mathrm{cm} /$ tiller/d in koronivia grass $(\mathrm{P}<0.05)$. During the dry season, LElR did not differ between cultivars $(\mathrm{P}>0.05)$, but for most grasses LEIR in the wet season exceeded $(\mathrm{P}<0.05)$ that in the dry season.

Rate of leaf senescence did not differ $(\mathrm{P}>0.05)$ among the grasses or between seasons (Table 3 ).

Stem elongation rate (SER) during the rainy season varied from $0.55 \mathrm{~cm} / \mathrm{d}$ in Marandu and gamba grass to $0.06 \mathrm{~cm} / \mathrm{d}$ in Massai $(\mathrm{P}<0.05)$ (Table 3). While there were no differences among the grasses during the dry season $(\mathrm{P}>0.05)$, SERs during the dry season were much lower than during the wet season.

Table 2. Total forage production, leaf:stem ratio, tiller population density and number of dead tillers of 9 tropical forage grasses during the second rainy and dry seasons (2011).

\begin{tabular}{|c|c|c|c|c|c|c|c|c|c|}
\hline \multirow[t]{2}{*}{$\overline{\text { Cultivar }}$} & \multicolumn{3}{|c|}{ Forage production (kg DM/ha) ${ }^{1}$} & \multicolumn{2}{|c|}{ Leaf:stem ratio $^{1}$} & \multicolumn{2}{|c|}{$\begin{array}{c}\text { Tiller population } \\
\left.\text { density (tillers } / \mathrm{m}^{2}\right)^{1}\end{array}$} & \multicolumn{2}{|c|}{$\begin{array}{l}\text { Number of dead } \\
\text { tillers }\left(\text { No. } / \mathrm{m}^{2}\right)^{1}\end{array}$} \\
\hline & Annual $^{2}$ & Rainy & Dry & Rainy & Dry & Rainy & Dry & Rainy & Dry \\
\hline Koronivia grass & 18,669ABC & 14,160CDa & 4,509Ab & 3.0ABa & 7.1ABa & 521.4Aa & 104.4BCDb & $113.1 \mathrm{ABa}$ & 75.7ABa \\
\hline Marandu & $20,102 \mathrm{AB}$ & 16,351BCDa & 3,752Ab & $2.6 \mathrm{Bb}$ & 9.1ABa & 169.2ABa & 98.3Db & 55.8BCa & $55.8 \mathrm{Ba}$ \\
\hline Xaraés & $23,330 \mathrm{~A}$ & $18,150 \mathrm{ABa}$ & $4,662 \mathrm{Ab}$ & 3.5ABa & 8.7ABa & $134.7 \mathrm{Ba}$ & 111.2BCDa & 48.0Ca & $94.5 \mathrm{ABa}$ \\
\hline Piatã & $8,235 \mathrm{C}$ & 14,637CDa & 3,599Ab & $.2 \mathrm{ABa}$ & 9.1ABa & $174.5 \mathrm{ABa}$ & 99.6CDb & $45.8 \mathrm{Ca}$ & $90.7 \mathrm{ABa}$ \\
\hline Mulato & $25,311 \mathrm{~A}$ & $20,850 \mathrm{Aa}$ & $5,180 \mathrm{Ab}$ & 5.6ABa & 8.2ABa & 168.9ABa & 169.1ABCa & 46.8Ca & $76.5 \mathrm{ABa}$ \\
\hline Signal grass & $16,042 \mathrm{BC}$ & 13,375Da & $2,668 \mathrm{Ab}$ & 4.7ABa & 5.9Ba & 168.7ABa & 105.9BCDa & 48.8Ca & $80.5 \mathrm{ABa}$ \\
\hline Ruzi grass & $14,901 \mathrm{BC}$ & 13,098Da & $1,803 \mathrm{Ab}$ & 4.2ABa & 7.7ABa & $126.8 \mathrm{Ba}$ & 81.7Da & $38.4 \mathrm{Ca}$ & $59.5 \mathrm{Ba}$ \\
\hline Massai & $11,653 \mathrm{BC}$ & 8,939Ea & $2,714 \mathrm{Ab}$ & 8.3Аа & 13.1Aa & 356.7Aa & 346.7Aa & 125.4Aa & 150.1Aa \\
\hline Gamba grass & $20,006 \mathrm{AB}$ & $17,025 \mathrm{BCa}$ & $2,981 \mathrm{Ab}$ & 1.7Ba & 6.0Ba & 174.7ABa & 281.7Aa & $48.15 \mathrm{Cb}$ & 140.9Aa \\
\hline
\end{tabular}

${ }^{1}$ Within parameters, medians followed by the same letter, upper case in columns and lower case in rows, do not differ by Student's t-test $(\mathrm{P}>0.05)$.

${ }^{2}$ Means followed by the same letter do not differ by Student's t-test $(\mathrm{P}>0.05)$. 
Table 3. Morphogenic characteristics of 9 tropical forage grasses in rainy and dry seasons of the second year (2011).

\begin{tabular}{|c|c|c|c|c|c|c|c|c|c|c|}
\hline \multirow{2}{*}{$\begin{array}{l}\text { Cultivar } \\
\text { Season }\end{array}$} & \multicolumn{2}{|c|}{$\begin{array}{l}\text { Leaf emergence } \\
\text { rate }(\mathrm{cm} / \text { tiller/d) }\end{array}$} & \multicolumn{2}{|c|}{$\begin{array}{l}\text { Phyllochron } \\
\text { (d/leaf) }\end{array}$} & \multicolumn{2}{|c|}{$\begin{array}{l}\text { Leaf elongation } \\
\text { rate }(\mathrm{cm} / \text { tiller/d) }\end{array}$} & \multicolumn{2}{|c|}{$\begin{array}{l}\text { Rate of leaf senes- } \\
\text { cence (cm/tiller/d) }\end{array}$} & \multicolumn{2}{|c|}{$\begin{array}{l}\text { Stem elongation } \\
\text { rate }(\mathrm{cm} / \mathrm{d})\end{array}$} \\
\hline & Rainy & Dry & Rainy & Dry & Rainy & Dry & Rainy & Dry & Rainy & Dry \\
\hline Koronivia grass & $0.13 \mathrm{Aa}^{1}$ & $0.05 \mathrm{Aa}$ & 8.0Aa & $20.3 \mathrm{Ba}$ & $1.27 \mathrm{Ba}$ & $0.29 \mathrm{Aa}$ & $0.09 \mathrm{Aa}$ & $0.23 \mathrm{Aa}$ & $0.12 \mathrm{ABa}$ & $0.06 \mathrm{Aa}$ \\
\hline Marandu & $0.11 \mathrm{Aa}$ & $0.03 \mathrm{Bb}$ & $9.3 \mathrm{Ab}$ & $30.4 \mathrm{ABa}$ & 3.74ABa & $0.41 \mathrm{Ab}$ & $0.57 \mathrm{Aa}$ & $0.50 \mathrm{Aa}$ & $0.55 \mathrm{Aa}$ & $0.02 \mathrm{Ab}$ \\
\hline Xaraés & 0.09Aa & $0.03 \mathrm{Bb}$ & $25.1 \mathrm{Ab}$ & 61.0Aa & 4.72ABa & $0.56 \mathrm{Ab}$ & $0.68 \mathrm{Aa}$ & $0.60 \mathrm{Aa}$ & $0.44 \mathrm{Aa}$ & $0.04 \mathrm{Ab}$ \\
\hline Piatã & 0.09Aa & $0.03 \mathrm{ABb}$ & $11.2 \mathrm{Ab}$ & 33.0ABa & 2.72ABa & 0.59Aa & $0.61 \mathrm{Aa}$ & $0.61 \mathrm{Aa}$ & $0.27 \mathrm{ABa}$ & $0.06 \mathrm{Aa}$ \\
\hline Mulato & $0.10 \mathrm{Aa}$ & $0.04 \mathrm{ABa}$ & 10.3Aa & $30.3 \mathrm{ABa}$ & 2.93ABa & $0.35 \mathrm{Ab}$ & 0.82Aa & $0.60 \mathrm{Aa}$ & $0.29 \mathrm{ABa}$ & $0.05 \mathrm{Ab}$ \\
\hline Signal grass & 0.11Аa & $0.04 \mathrm{ABb}$ & 9.3Ab & 27.1ABa & 2.41ABa & 0.37Aa & $0.47 \mathrm{Aa}$ & 0.57Aa & $0.33 \mathrm{ABa}$ & $0.07 \mathrm{Aa}$ \\
\hline Ruzi grass & $0.11 \mathrm{Aa}$ & $0.05 \mathrm{ABa}$ & 9.3Аа & $22.5 \mathrm{ABa}$ & $3.23 \mathrm{ABa}$ & $0.25 \mathrm{Ab}$ & $0.55 \mathrm{Aa}$ & $0.57 \mathrm{Aa}$ & $0.29 \mathrm{ABa}$ & $0.03 \mathrm{Ab}$ \\
\hline Massai & 0.07Aa & $0.02 \mathrm{Bb}$ & $14.0 \mathrm{Ab}$ & $48.0 \mathrm{Aa}$ & 2.64ABa & $0.29 \mathrm{Ab}$ & 0.61Aa & 0.43Aa & $0.06 \mathrm{Ba}$ & $0.02 \mathrm{Aa}$ \\
\hline Gamba grass & $0.13 \mathrm{Aa}$ & $0.04 \mathrm{ABb}$ & 8.0Ab & $34.1 \mathrm{ABa}$ & 6.02Aa & $0.54 \mathrm{Ab}$ & $1.43 \mathrm{Aa}$ & 0.62Aa & $0.55 \mathrm{Aa}$ & $0.07 \mathrm{Ab}$ \\
\hline
\end{tabular}

${ }^{1}$ Within parameters, medians followed by the same letter, upper case in columns and lower case in rows, do not differ by Student's t-test $(\mathrm{P}>0.05)$.

Life-spans of leaves did not differ $(\mathrm{P}>0.05)$ among the grasses in either the rainy or the dry season, but leaves generally lived longer during the dry season $(\mathrm{P}<0.05)$ (Table 4).

The final length of the leaf blade (FLLB) during the rainy season varied from $26.8 \mathrm{~cm}$ in gamba grass and $24.8 \mathrm{~cm}$ in Xaraés to $8.4 \mathrm{~cm}$ in koronivia grass $(\mathrm{P}<0.05)$ (Table 4). During the dry season, the range in FLLB was $12.0 \mathrm{~cm}$ in gamba grass to $6.8 \mathrm{~cm}$ in koronivia grass $(\mathrm{P}<0.05)$. FLLB in the dry season was lower than that in the rainy season for all cultivars, but differences were not always significant.

The number of live leaves per tiller (NFLT) during the rainy season ranged from 6.38 leaves/tiller for koronivia grass to 3.5 leaves/tiller for Piatã $(\mathrm{P}<0.05)$ (Table 4). During the dry season, the range was from 4.51 leaves/tiller for koronivia grass to 2.13 leaves/tiller for Massai and gamba grass $(\mathrm{P}<0.05)$. Fewer new leaves appeared in the dry season than in the rainy season for most cultivars $(\mathrm{P}<0.05)$.

The density of living tillers did not differ among cultivars during the rainy season $(\mathrm{P}>0.05)$, despite a range from 20.05 tillers/plant in ruzi grass to 7.5 tillers/plant in Xaraés (Table 4). During the dry season, the range was from 12.63 tillers/plant in Massai and 10.03 tillers/plant in gamba grass to 2.13 tillers/plant in koronivia grass and Mulato and 2.07 tillers/plant in signal grass $(\mathrm{P}<0.05)$.

Table 4. Structural characteristics of 9 tropical forage grasses in rainy and dry seasons of the second year (2011).

\begin{tabular}{|c|c|c|c|c|c|c|c|c|}
\hline \multirow[t]{2}{*}{ Cultivar } & \multicolumn{2}{|c|}{$\begin{array}{c}\text { Life span of leaves } \\
(\mathrm{d})^{1}\end{array}$} & \multicolumn{2}{|c|}{$\begin{array}{c}\text { Final length of leaf } \\
\text { blade }(\mathrm{cm})^{2}\end{array}$} & \multicolumn{2}{|c|}{$\begin{array}{c}\text { Number of live leaves } \\
\text { per tiller }\end{array}$} & \multicolumn{2}{|c|}{$\begin{array}{c}\text { Density of living tillers } \\
\text { (tillers/plant) }^{1}\end{array}$} \\
\hline & Rainy & Dry & Rainy & Dry & Rainy & Dry & Rainy & Dry \\
\hline Koronivia grass & $17.4 \mathrm{Ab}$ & $30.7 \mathrm{Aa}$ & $8.4 \mathrm{Fa}$ & 6.8Ca & 6.38Aa & $4.51 \mathrm{Aa}$ & $8.75 \mathrm{Aa}$ & 2.13BCDb \\
\hline Marandu & $18.3 \mathrm{Ab}$ & $29.7 \mathrm{Aa}$ & 17.7CDa & $11.7 \mathrm{ABb}$ & 4.50ABa & $2.66 \mathrm{Cb}$ & $15.75 \mathrm{Aa}$ & 2.63CDb \\
\hline Xaraés & 12.9Ab & 27.9Aа & 24.6ABa & $14.0 \mathrm{Ab}$ & 4.50ABa & $2.57 \mathrm{Cb}$ & 7.50Aa & 3.76ABCDa \\
\hline Piatã & $14.8 \mathrm{Ab}$ & 27.6Aa & 14.7DEa & 11.2ABCa & $3.50 \mathrm{Ba}$ & 2.81BCa & $10.25 \mathrm{Aa}$ & 3.44ABCDa \\
\hline Mulato & 15.8Aa & 26.8Aa & 17.4CDEa & 9.9ABCb & 4.38ABa & 3.00ABCb & $12.25 \mathrm{Aa}$ & $2.14 \mathrm{CDb}$ \\
\hline Signal grass & $13.4 \mathrm{Ab}$ & $24.7 \mathrm{Aa}$ & $12.8 \mathrm{EFa}$ & 8.8BCa & 4.63ABa & 2.94ABCb & $9.50 \mathrm{Aa}$ & $2.07 \mathrm{Db}$ \\
\hline Ruzi grass & 14.8Aa & 21.6Aa & 16.6DEa & 8.2BCb & 3.63Ba & $2.72 \mathrm{Ca}$ & 20.05Aa & 3.13ABCDb \\
\hline Massai & $16.2 \mathrm{Ab}$ & $25.4 \mathrm{Aa}$ & 21.9BCa & 10.9ABCb & 3.75Aa & $2.13 \mathrm{Cb}$ & 17.00Aa & 12.63Aa \\
\hline Gamba grass & $11.1 \mathrm{Ab}$ & $24.0 \mathrm{Aa}$ & 26.8Aa & $12.0 \mathrm{ABb}$ & 4.00ABa & $2.13 \mathrm{Cb}$ & $13.25 \mathrm{Aa}$ & 10.03ABCa \\
\hline
\end{tabular}

${ }^{1}$ Within parameters, medians followed by the same letter, upper case in columns and lower case in rows, do not differ by Student's t-test $(\mathrm{P}>0.05)$.

${ }^{2}$ Within parameters, means followed by the same letter, upper case in columns and lower case in rows, do not differ by Student's ttest $(\mathrm{P}>0.05)$. 


\section{Discussion}

This study has provided valuable information on the comparative production of 9 different grasses in northeast Brazil, which will complement data from other regions. The data collected on morphology and structural characteristics help to explain why some grasses are more productive than others and provide some indications of the likely value of the different cultivars for beef production in the region and how they might be managed. The absence of significant differences between cultivars for some parameters suggests that there was large variation between samples and a greater number of samples per plot or larger samples per plot could have improved the ability to determine differences.

In terms of DM production, Mulato was outstanding throughout the study, with highest production in both the establishment year and the second year. Xaraés and Massai also had good yields in the establishment year, while koronivia grass, gamba grass and Marandu produced good yields in the second year, which was related to greater rainfall in the second year (Figure 1), and shows the greater sensitivity of these species to water stress. In a comparison of 5 cultivars from the Brachiaria genus in Mato Grosso, Bauer et al. (2011) also found highest production in Mulato followed by Xaraés (4,200 vs. $3,500 \mathrm{~kg} / \mathrm{ha}$ ). In our research, the high production by Mulato in the establishment year would have been affected by the absence of dead tillers in this cultivar. It has stems with large diameter and hence greater weight than other grasses like Massai, which has thinner and lighter stems.

Dry matter yield is not the only criterion to be considered, as leaf:stem ratio has a marked effect on the quality of the forage produced and the amount of material preferred by grazing animals. The cultivar with outstanding leaf:stem ratio was Massai in both years, as was shown previously by Brâncio et al. (2003) in comparisons of 3 cultivars of Panicum maximum in Campo Grande, Mato Grosso do Sul. Despite the fact that it produced only $54 \%$ as much dry matter as Mulato in the establishment year, its much higher leaf:stem ratio (13.5 vs. 1.3) resulted in leaf production of $9,436 \mathrm{~kg} / \mathrm{ha}$ compared with 10,629 kg/ha for Mulato, a difference of only $11 \%$. The high leaf production by Massai was probably a function of the high tiller population density (TPD) of this cultivar (104 tillers $/ \mathrm{m}^{2}$ ) compared with 29-48 till$\mathrm{ers} / \mathrm{m}^{2}$ for the remaining grasses. Despite having the highest TPD in rainy and dry seasons, the lowest leaf elongation rate, low stem elongation rate and taking a long time to exhibit consecutive leaves (14-48 days), Massai had high numbers of dead tillers in rainy and dry seasons, which certainly contributed to the lower yield obtained. Nevertheless, this species has great ability to recover after droughts, being one of the first to recover after the first rains, along with gamba grass. Ruzi grass, Piatã and signal grass recovered slowly after a period of prolonged drought, which was associated with high tiller mortality.

The superior dry matter production of Mulato continued into the second year, when Massai produced only $46 \%$ as much total forage as Mulato. Leaf:stem ratio did not favor Massai to the same extent as in the establishment year ( 8.3 vs. 5.6 for Mulato in the rainy season; and 13.1 vs. 8.2 for Mulato in the dry season). Interestingly, species like koronivia grass and gamba grass, which produced low yields in the establishment year, produced much higher total yields in the second year (18,000-20,000 kg DM/ha). Koronivia grass had a high leaf emergence rate and number of live leaves per tiller and low stem elongation rate, and took the shortest time to exhibit 2 consecutive leaves, which compensates for the lowest final length of leaf blade.

Gamba grass and B. brizantha cvv. Marandu and Xaraés had higher leaf and stem elongation rates, and higher final length of leaf blade (Table 4), which resulted in higher yields, since the stem is the structural component with higher weight than leaves, and is larger, contributing to increased total forage production.

While all cultivars showed marked seasonality of production as a result of climatic factors, ruzi grass showed the highest level of seasonality and produced only $14 \%$ as much forage in the dry season as in the wet. Most grasses produced 20-25\% as much in the dry as in the wet, while koronivia grass and Massai showed least effect, producing $30-32 \%$ as much in the dry season. Generally, the higher the production during the rainy season, the greater the seasonality of production. This marked seasonality in forage production causes a number of problems, including both availability of fodder for animals and forage quality at the more critical times of year (Pedreira 1973).

The results obtained in this study for Xaraés and Piatã differed from those reported by Euclides et al. (2008), who found a lower leaf:stem ratio (LSR) for Piatã in the rainy season and Xaraés in the dry season; according to these authors, this result indicates that grazing management should be different for these cultivars. In our study, LSR was markedly higher in the dry season than in the wet season for both cultivars, so other criteria would determine if these cultivars should be managed differently.

Leaf:stem ratio is arguably the most important structural characteristic of pasture grasses. According to Pinto 
et al. (1994), a critical threshold for LSR has been considered to be 1.0 , with values lower than this causing a fall in the quantity and quality of the forage produced. While some cultivars in our study had values below or near 1.0 in the establishment year, values for all cultivars exceeded 1.0 in both seasons in the second year. There was no difference in LSR between the rainy and dry seasons, as the higher water deficit, caused by minimal variations in temperature, led to lower stem elongation and leaf length.

Ruzi grass presented the greatest number of dead tillers, which is related to the lower adaptation of this species to the soil and climatic conditions in the study area. Xaraés and ruzi grass had the lowest tiller population density (TPD), but species with high TPD did not present a corresponding increment in biomass, possibly due to their morphological characteristics, which can be evidenced by the smaller number of live leaves per tiller, smaller final length of the leaf blade and slower leaf emergence rate presented. The lower DM yields in the dry period than in the rainy season reflect the lower TPD during the dry through water limitations. Formation, development, growth and senescence of tillers are influenced by climatic conditions, such as temperature, water and nutrient availability (Mazzanti et al. 1994; Fagundes et al. 2006).

In general, higher mortality of tillers occurred in the dry season, which, according to Fagundes et al. (2006), is a result of the plants' specific mechanisms for limiting the breathable area and coping with the worsening water deficiency. These mechanisms include the inhibition of tillering and branching, the anticipation of established tiller death, reduction of the leaf area accelerating the senescence of older leaves, and the further growth of the root system (Morales et al. 1997). Nabinger and Pontes (2001) suggested that, to maintain the development of tillers in growth-limiting conditions, it seems logical that plants would first compromise tillering, rather than reducing the size and life-span of leaves. Understanding the density behavior of living and dead tillers can be an important strategy for the management of pasture, because the density of tillers determines the durability of the pasture (Lemaire and Chapman 1996).

\section{Conclusions}

While DM yields of the forage grasses studied differed in both wet and dry seasons, in general all cultivars followed a similar pattern of behavior with lower growth, higher leaf:stem ratio, higher phyllochron, lower leaf elongation rate and longer leaf lifespan in the dry season. Mulato, Xaraés and gamba grass showed highest DM production, making them an attractive option for livestock feeding, but the high leaf:stem ratio for Massai offsets to some extent the lower DM yields of this cultivar.

\section{Acknowledgments}

The authors acknowledge FAPEMA (Fundação de Amparo à Pesquisa e ao Desenvolvimento Científico e Tecnológico do Maranhão) for financial support and FOPAMA (Grupo de Estudos, Pesquisa e Extensão) for help in conducting the experiment.

\section{References}

Bauer MO; Pacheco LPA; Chichorro JF; Vasconcelos LV; Pereira DFC. 2011. Produção e características estruturais de cinco forrageiras do gênero Brachiaria sob intensidades de cortes intermitentes. Ciência Animal Brasileira 12:17-25. http://goo.gl/CbBeWI

Brâncio P; Euclides VPB; Nascimento Jr D; Fonseca DM; Almeida RG; Macedo MCM; Barbosa RA. 2003. Avaliação de três cultivares de Panicum maximum Jacq. sob pastejo: Disponibilidade de forragem, altura do resíduo pós-pastejo e participação de folhas, colmos e material morto. Revista Brasileira de Zootecnia 32:5563. http://goo.gl/0zV9Uu

Euclides VPB; Macedo MCM; Valle CB; Barbosa RA; Gonçalves WV. 2008. Produção de forragem e características da estrutura do dossel de cultivares de Brachiaria brizantha sob pastejo. Pesquisa Agropecuária Brasileira 43:1805-1812. http://goo.gl/ACuvVh

Fagundes JL; Fonseca DM; Mistura C; Morais RV; Vitor CMT; Gomide JA; Nascimento Jr D; Casagrande DR; Costa LC. 2006. Características morfogênicas e estruturais do capim-braquiária em pastagem adubada com nitrogênio avaliadas nas quatro estações do ano. Revista Brasileira de Zootecnia 35:21-29. http://goo.gl/ MAUR5K

Faria AFG; Pedreira CGS; Pequeno DNL; Silva LS; Nguluve DW; Ferreira ANS. 2013. Morphogenic responses of two Brachiaria genotypes to clipping frequency. Tropical Grasslands - Forrajes Tropicales 1:71-73. http://goo.gl/ uX2uI5

IBGE (Instituto Brasileiro de Geografia e Estatística). 2004. http://goo.gl/QXtrPl

Lemaire G; Chapman D. 1996. Tissue flows in grazed plant communities. In: Hodgson J; Illius AW, eds. The ecology and management of grazing systems. CAB International, Wallingford, UK. p. 3-36.

Macedo MCM. 2005. Pastagens no ecossistema cerrados: Evolução das pesquisas para o desenvolvimento sustentável. Anais da 42 Reunião Anual da Sociedade Brasileira de Zootecnia, Goiânia, GO, Brazil. p. 56-84.

Mazzanti A; Lemaire G; Gastal F. 1994. The effect of nitrogen fertilization upon the herbage production of tall fescue 
swards continuously grazed with sheep. 1. Herbage growth dynamics. Grass and Forage Science 49:111120. http://goo.gl/FpZFdU

Morales AS; Nabinger C; Maraschin GE; Rosa LMG. 1997. Efeito da disponibilidade hídrica sobre a morfogênese e a repartição de assimilados em $L$. corniculatus L. cv. São Gabriel. Anais da 34 Reunião Anual da Sociedade Brasileira de Zootecnia, Juiz de Fora, MG, Brazil. p. 124-126.

Nabinger C; Pontes L. 2001. Manejo da desfolha. Anais do 14 Simpósio sobre Manejo da Pastagem, Piracicaba, SP, Brazil. p. 192-210.

Nascimento MPSCB; Renvoize SA. 2001. Gramíneas forrageiras naturais e cultivadas na região Meio-Norte. 1st Edn. Embrapa Meio-Norte, Teresina, PI, Brazil.
Pedreira JVS. 1973. Crescimento estacional dos capins colonião Panicum maximum Jacq., gordura Melinis minutiflora Pal de Beauv., jaraguá Hyparrhenia rufa (Ness) Stapf e pangola de Taiwan A-24 Digitaria pentzii Stent. Boletim da Indústria Animal 30(1):59-145.

Pinto JC; Gomide JA; Maestri M. 1994. Crescimento de folhas de gramíneas forrageiras tropicais, cultivadas em vasos, com duas doses de nitrogênio. Revista da Sociedade Brasileira de Zootecnia 23:327-332.

Vilela H. 2012. Série gramíneas tropicais - Gênero Panicum (Panicum maximum - Massai Capim). http://goo.gl/ 8jsXbf

\section{(Received for publication 19 October 2013; accepted 28 April 2014)}

(C) 2014

\section{(c) (i) (3) (2)}

Tropical Grasslands-Forrajes Tropicales is an open-access journal published by Centro Internacional de Agricultura Tropical (CIAT). This work is licensed under a Creative Commons Attribution-NonCommercial-ShareAlike 3.0 Unported License. To view a copy of this license, visit http://creativecommons.org/licenses/by-nc-sa/3.0/ 
Rodrigues RC; Sousa TVR; Melo MAA; Araújo JS; Lana RP; Costa CS; Oliveira ME; Parente MOM; Sampaio IBM. 2014. Agronomic, morphogenic and structural characteristics of tropical forage grasses in northeast Brazil. Tropical Grasslands - Forrajes Tropicales 2:214-222.

DOI: $\underline{10.17138 / \mathrm{TGFT}(2) 214-222}$ 